\title{
Genetic variability of Corynespora cassiicola isolates from Amazonas, Brazil
}

\author{
Variabilidade genética de Corynespora cassiicola isolados do Amazonas, Brasil \\ Jânia Lília da Silva Bentes ${ }^{*}$ (D), Francy Mary Galúcio Sousa', Maria Teresa Gomes Lopes' ${ }^{1 D}$, \\ Mágno Sávio Ferreira Valente', Fabíola Viana Almeida', Liane Cristine Rebouças Demosthenes'
}

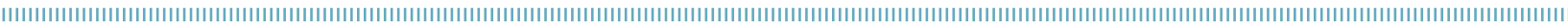

\begin{abstract}
Corynespora cassiicola is a cosmopolitan ascomycete widely known as phytopathogen in several crops, and more recently as an emerging pathogen in humans. In this study the genetic variability of 60 isolates of Corynespora cassiicola from different hosts and cities of Amazonas was evaluated, using AFLP molecular markers. Seven genetic groups were identified according to a dendrogram obtained by the Unweighted Pair Group Method using Arithmetical Averages, indicating significant variability among the isolates. Three isolates of different hosts (28, obtained from papaya; 55 , obtained from cucumber; and 58, from tomato) remained as single individuals in distinct groups, suggesting marked genetic variation in comparison to the other isolates and possible specificity by the host.
\end{abstract}

KEYWORDS: pathogenicity; target spot; Amplified Fragment Length Polymorphism.
RESUMO: Corynespora cassiicola é um ascomiceto cosmopolita amplamente conhecido como fitopatógeno em diversas culturas e, mais recentemente, como patógeno emergente em humanos. Na regiáo Norte do Brasil é responsável por perdas significativas em cultivos tanto em casa de vegetaçáo como em campo aberto. Neste estudo foi avaliada a variabilidade genética de 60 isolados de Corynespora cassiicola procedentes de diferentes hospedeiras e municípios do Amazonas, usando marcadores moleculares AFLP. Foram identificados sete grupos genéticos de acordo com dendrograma obtido pelo método de agrupamento UPGMA, indicando significativa variabilidade entre os isolados. Três isolados de diferentes hospedeiras (isolado 28, obtido de mamoeiro; isolado 55, obtido de pepineiro; e isolado 58, proveniente de tomateiro) permaneceram como indivíduos únicos em grupos distintos, sugerindo variação genética marcante em comparação com os demais e possível especificidade pela hospedeira de origem.

PALAVRAS-CHAVE: patogenicidade; mancha-alvo; Polimorfismo de Comprimento de Fragmentos Amplificados. 
The Corynespora cassicola (Berk. \& Curt.) Wei. is a cosmopolitan phytopathogen reported to cause disease in more than 70 plant species (VERZIGNASSI et al., 2003). The disease management has been done basically through cultural practices and with the use of fungicides recommended for other phytopathogens.

This fungi can vary in morphology and virulence presenting specificity or different degrees of virulence in the same host, which may indicate the occurrence of physiological races (DIXON et al., 2009; SHIMOMOTO et al., 2011). SOUSA; BENTES (2014) observed a wide range of morphometric characters of conidia and conidiophores, demonstrating the plasticity in these characters in isolates. This variation reflects the genetic variability in this genus, with implication in the durability of the resistance of cultivars.

Molecular techniques for genetic analysis have become important tools for analysis of diversity and epidemiology in phytopathogens. The Amplified Fragment Length Polymorphism (AFLP) technique allows the analysis of a large number of loci per reaction with reproducibility of results (VOS et al., 1995), and can also be applied to gene segregation studies, aiming to determine the genetic and molecular bases of biological phenomena in phytopathogenic fungi, virulence and taxonomic studies (SILVA-MANN et al., 2005). Genetic variability studies in C. cassicola have been carried out mainly with isolates from rubber tree (Hevea brasiliensis) using Random Amplified Polymorphic DNA (RAPD) molecular markers (KURT, 2005) and Inter Simple Sequence Repeat (ISSR) (QI et al., 2011). The objective of this work was to evaluate the genetic diversity of Corynespora cassiicola isolates from different plant hosts, using AFLP markers, in order to provide subsidies for the management of the disease, based on knowledge of pathogen variability.

Sixty isolates of $C$. cassiicola were obtained from leaves of tomato, cucumber, eggplant and papaya plants collected in crop fields in Manaus, Presidente Figueiredo and Iranduba, in Amazonas, Brazil (Table 1).

Table 1. Origin of Corynespora cassiicola isolates according to host and collection site in Amazon state.

\begin{tabular}{|c|c|c|c|c|c|}
\hline Isolate & Host & Collection site & Isolate & Host & Collection site \\
\hline 1 & Tomato & Manaus & 31 & Papaya & P. Figueiredo \\
\hline 2 & Tomato & Manaus & 32 & Tomato & Manaus \\
\hline 3 & Tomato & Manaus & 33 & Papaya & P. Figueiredo \\
\hline 4 & Cucumber & P. Figueiredo* & 34 & Cucumber & Iranduba \\
\hline 5 & Cucumber & P. Figueiredo & 35 & Tomato & P. Figueiredo \\
\hline 6 & Papaya & P. Figueiredo & 36 & Cucumber & Manaus \\
\hline 7 & Papaya & Manaus & 37 & Cucumber & Manaus \\
\hline 8 & Tomato & Iranduba & 38 & Cucumber & Manaus \\
\hline 9 & Tomato & Iranduba & 39 & Cucumber & Manaus \\
\hline 10 & Tomato & Iranduba & 40 & Papaya & P. Figueiredo \\
\hline 11 & Papaya & Iranduba & 41 & Cucumber & P. Figueiredo \\
\hline 12 & Papaya & Iranduba & 42 & Papaya & P. Figueiredo \\
\hline 13 & Cucumber & Manaus & 43 & Papaya & Iranduba \\
\hline 14 & Cucumber & Manaus & 44 & Tomato & Iranduba \\
\hline 15 & Cucumber & Manaus & 45 & Cucumber & Iranduba \\
\hline 16 & Cucumber & Manaus & 46 & Tomato & Iranduba \\
\hline 17 & Cucumber & Manaus & 47 & Tomato & Iranduba \\
\hline 18 & Papaya & Manaus & 48 & Cucumber & Iranduba \\
\hline 19 & Tomato & Iranduba & 49 & Tomato & Iranduba \\
\hline 20 & Tomato & Iranduba & 50 & Tomato & Iranduba \\
\hline 21 & Tomato & Iranduba & 51 & Cucumber & Iranduba \\
\hline 22 & Tomato & Iranduba & 52 & Cucumber & Iranduba \\
\hline 23 & Cucumber & Manaus & 53 & Tomato & Manaus \\
\hline 24 & Papaya & Iranduba & 54 & Tomato & Manaus \\
\hline 25 & Papaya & P. Figueiredo & 55 & Cucumber & Iranduba \\
\hline 26 & Papaya & Iranduba & 56 & Tomato & Manaus \\
\hline 27 & Papaya & Iranduba & 57 & Tomato & Manaus \\
\hline 28 & Papaya & Manaus & 58 & Tomato & Manaus \\
\hline 29 & Papaya & Manaus & 59 & Papaya & Iranduba \\
\hline 30 & Papaya & Manaus & 60 & Papaya & Iranduba \\
\hline
\end{tabular}

*Presidente Figueiredo. 
Leaves with typical target spot were taken to the laboratory for indirect isolation of the pathogen in potato-dextroseagar (PDA) culture medium. The isolates were stored in test tubes with PDA medium at $28^{\circ} \mathrm{C}$ without lighting. To confirm the isolates species, a morphometric evaluation of the conidia was carried out. The length and width of one hundred conidia of each isolate were taken using a micrometer eyepiece under the Olympus CX40 (Japan) optical microscope. The data obtained were compared with those described in the literature (ELLIS, 1971).

Purification of genomic DNA was done from monosporic cultures of 60 pathogen isolates, obtained according to PINHO et al. (2016), grown in $200 \mathrm{~mL}$ potato-dextrose (PD), under continuous stirring at $120 \mathrm{rpm}$ for five days at $26^{\circ} \mathrm{C}$. The mycelium was collected by vacuum filtration using a $0.45 \mu \mathrm{m}$ filter (Milipore ${ }^{\circledR}$, USA) in a laminar flow chamber. The DNA was extracted by the phenol/chloroform method described by RAEDER; BRODA (1985) with adaptations. Maceration of the mycelium of the fungus was done in $2 \%$ Cetyltrimethyl ammonium bromide (CTAB) buffer (Tris 2.42 g, $\mathrm{NaCl} 8.2 \mathrm{~g}$, EDTA $0,74 \mathrm{~g}$, Mili-Q Water $100 \mathrm{~mL}$ ) and silica (silicon dioxide, 10-20 nm particles, Sigma-Aldrich, United States). The quantification of DNA was measured in a spectrophotometer NanoDrop ${ }^{\circledast} 2000$ Thermo Scientific and agarose gel electrophoresis $(0.8 \%)$ stained with ethidium bromide, using the Lambda molecular weight marker of $50 \mathrm{ng}$ and $100 \mathrm{ng}\left(105 \mathrm{ng}^{-1}\right.$, Jena Bioscience, Germany). The visualization of amplified fragments was performed on ultraviolet transilluminator (Loccus Biotecnology $y^{\circledR}$ ).

AFLP analyzes were performed according to the method described by VOS et al. (1995). Aliquots of $10 \mu \mathrm{l}$ of genomic DNA (50-250 ng $\mu \mathrm{L}^{-1}$ ) were digested with the EcoRI (Invitrogen, São Paulo) and MseI (NEB, São Paulo) enzymes at $37^{\circ} \mathrm{C}$ for three hours, and heated at $70^{\circ} \mathrm{C}$ for 15 minutes for the inactivation of the enzymes. The DNA fragments were ligated to the EcoRI R adapters (5' AAT TGG TAC GCA GTC TA C 3'); EcoRI F (5 'CTC GTA GAC TGC GTA CC 3') and MseI R (5' TAC TCA GGA CTC AT 3'); MseIF (5 'GAC GAT GAG TCC TGA G 3') (Invitrogen, São Paulo), at $23^{\circ} \mathrm{C}$ for three hours. After the binding reaction, the fragments were pre-amplified in 26 cycles of Polymerase Chain Reaction, with temperatures of 94,56 and $72^{\circ} \mathrm{C}$ for 60 seconds, in a thermocycler (Biocycler-Biosystem ${ }^{\oplus}$ ) using the combination of primers: EcoRI $+A$ and MseI $+A$; EcoRI $+C$ and MseI $+\mathrm{A} ; \mathrm{EcoRI}+\mathrm{G}$ and MseI + A. After the pre-amplification, the samples were diluted with $50 \mu \mathrm{L}$ of water.

For selective amplification of the DNA fragments, two nucleotides were used in four different combinations of primers: EcoRI + AT; EcoRI + GA; EcoRI + CC; EcoRI + AA. The effectiveness of each was investigated in combination with primer MseI + C. An aliquot of $3 \mu \mathrm{L}$ of pre-amplified DNA from each sample was subjected to selective amplification using 12 cycles of PCR with program: $94^{\circ} \mathrm{C}$ for 30 seconds; $65^{\circ} \mathrm{C}$ for 30 seconds; $72^{\circ} \mathrm{C}$ for 1 minute, followed by 23 cycles of $94^{\circ} \mathrm{C}$ for 30 seconds; $56^{\circ} \mathrm{C}$ for 30 seconds and $72^{\circ} \mathrm{C}$ for 1 minute. From each sample, $15 \mu \mathrm{l}$ of the PCR products were separated by electrophoresis on $6 \%$ polyacrylamide gel containing 7.5 M urea. The run was performed on Sequi-Gen GT equipment (BIO-RAD ${ }^{\circ}$, United States) for four hours at $80 \mathrm{~W}$ and $3.000 \mathrm{~V}$, with a temperature of $50^{\circ} \mathrm{C}$. The gel was revealed with silver nitrate (CRESTE et al., 2001).

For each sample in the gel, the presence of bands with molecular mass between 50 and 600 bp were quantified. From the fragments obtained, a binary matrix was constructed in which zero and one indicated absence and presence of fragments, respectively. The data obtained were used to construct a matrix of genetic distances between C. cassiicola isolates based on the Nei \& Li coefficient (NEI; LI, 1979). In order to visualize the genetic differentiation among the isolates, a dendrogram was constructed by Unweighted Pair Group Method using Arithmetical Averages (UPGMA) analyses with the aid of the statistical program R (R DEVELOPMENT CORE TEAM, 2013).

The number of amplified DNA fragments varied from 49 $(\mathrm{E}+\mathrm{GA} / \mathrm{M}+\mathrm{A})$ to $248(\mathrm{E}+\mathrm{AA} / \mathrm{M}+\mathrm{A})$, ranging in size from 50 to 600 bp. 428 fragments were evaluated, and 347 were polymorphic, corresponding to $87 \%$ of polymorphism.

The cophenetic correlation presented a value of $r=0.8964$. The genetic similarity varied according to the origin of the isolates and to the host plant, demonstrating an intra-specific variation, where isolates of the same origin and host were distributed in different groups (III, IV, V and VII). Estimates of genetic similarity between the isolates, obtained by the Nei and $\mathrm{Li}$ coefficient, ranged from 0.14 (among isolates 213-55) to 0.94 (isolates 14 and 15 ), with an average of 0.56 , indicating that a wide variability may occur among isolates.

According to a dendrogram generated from the AFLP data (Fig. 1), there were seven groups of isolates. Group I formed by isolate 55; Group II formed by isolate 28; Group III, with two isolates 49 and 50; Group IV with 48 isolates, the largest groups (isolates 59, 3, 4, 5, 6, 7, 11, 12, 18, 27, $22,23,25,26,17,16,13,14,15,29,30,60,48,51,38$, $45,33,31,34,41,43,40,42,1,2,32,53,36,47,10,24$, 19, 20); Group V with isolates 36, 37, 39, 52 and 54; Group VI with isolates 58; and Group VII with isolates 56 and 57.

Isolates 28, obtained from papaya, 55, obtained from cucumber, and 58, obtained from tomato, were addressed to groups I, II and VI respectively, suggesting some specificity by the host plant. Group V presents a large number of isolates, obtained from different hosts and fields (Table 1). Group VI has isolates obtained from cucumber with the exception of isolate 54, obtained from tomato, suggesting that there is specificity by the host, as well as for isolates 56 and 57 , in group VII, originated from tomato.

To determine the genetic patterns of population differentiation and structuring of the isolates, the bayesian analysis 


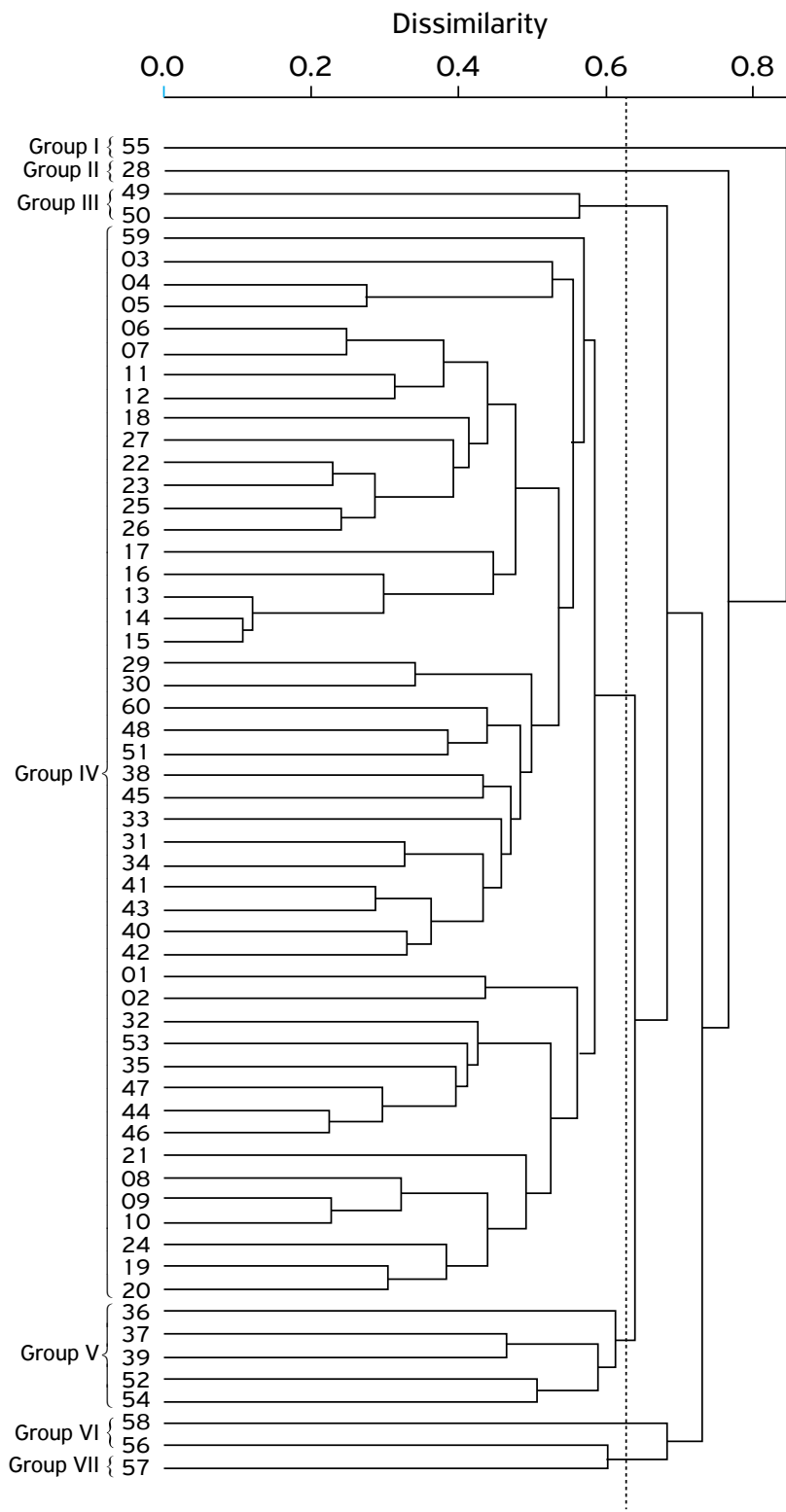

Figure 1. Dendrogram representative of the genetic divergence among 60 isolates of Corynespora cassiicola, obtained by the UPGMA method, using the Nei \& Li coefficient (NEI; LI, 1979) as a measure of dissimilarity. The horizontal dashed line represents the cut estimated by the method of MOJEMA (1977). was done by the Structure software and, according to the DK method described by EVANNO et al. (2005), the most likely number of clusters was $\mathrm{K}=4$ (Fig. 2). This result reveals a broad interaction between most isolates and different host species, indicating a gene flow where pathogenic isolates of a plant species are genetically related, which makes it possible for isolates to be pathogenic to more than one host species.

The molecular characterization of $C$. cassiicola isolates obtained from different hosts has been performed to detect genetic variations among the isolates (SILVA et al., 2003; KURT, 2005). The virulence in $C$. cassiicola may be associated with identifiable genetic variations at the molecular level (NGHIA et al., 2008; QI et al., 2011). The pathogenicity of C. cassiicola from Amazonas was studied on papaya, tomato and eggplant (FERREIRA; BENTES, 2017). The authors suggest the occurrence of more than one pathogen population in fields where the isolates were collected. Thus, the characterization of isolates from different hosts using AFLP markers allowed detecting variations that could be related to host specificity, as observed in isolates 28,55 and 58 . Since they remained as single individuals in distinct groups and are not genetically similar, it is possible that these could evolve to the appearance of physiological races of the pathogen. It was observed that a large number of isolates from different sources and hosts grouped together (Group IV), suggesting the lack of specificity of these isolates in relation to pathogenicity and geographic origin.

In natural populations of $C$. cassiicola in Amazonas, it is possible that both the physiological races of the pathogen and nonspecific interactions between isolates and different host plants occur, affecting directly the management of the disease.

\section{ACKNOWLEDGMENTS}

To National Council for Scientific and Technological Development (CNPq, Brazil) for the financial support of the research.

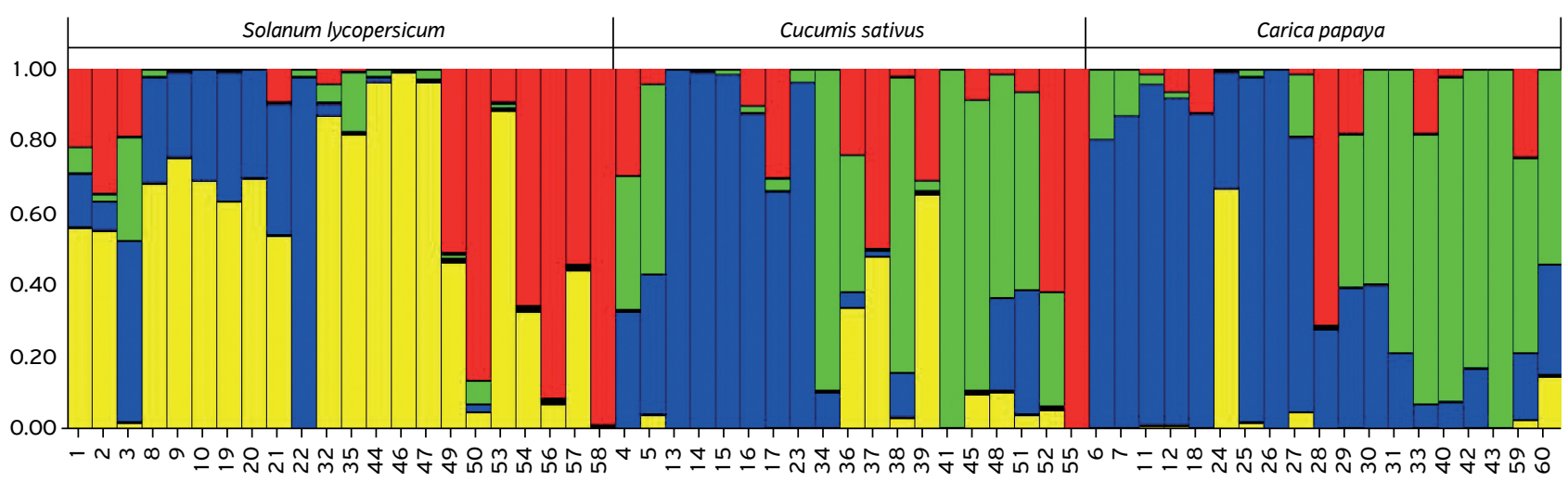

Figure 2. Population structure using the Structure software from 60 isolates of Corynespora cassiicola. 

REFERENCES

CRESTE, S.; TULMANN NETO, A.; FIGUEIRA, A. Detection of single sequence repeat polymorphisms in denaturing polyacrylamide sequencing gels by silver staining. Plant Molecular Biology Reporter, v. 19 n.4, p. 299-306, 2001.https://doi.org/10.1007/BF02772828

DIXON, L.J.; SCHLUB, R.L.; PERNEZNY, K.; DATNOFF, L.E. Host specialization and phylogenetic diversity of Corynespora cassiicola. Mycology, v.99, n.9, p.1015-1027, 2009. DOI: 10.1094/ PHYTO-99-9-1015

ELLIS, M.B. Dematiaceous Hyphomycetes. London: Commonwealth Mycological Institute, $1971.608 p$.

EVANNO, G.; REGNAUT, S.; GOUDET, J. Detecting the number of clusters of individuals using the software STRUCTURE: a simulation study. Molecular Ecology, v. 14, n.8, p.2611-2620, 2005. DOI: 10.1111/j.1365-294X.2005.02553.x

FERREIRA, A.F.T.A.F.; BENTES, J.L.S. Pathogenicity of Corynespora cassiicola on different hosts in Amazon State, Brazil. Summa Phytopathologica, v.43, n.1, p.63-65, 2017. http://dx.doi. org/10.1590/0100-5405/2220

KURT, S. Genetic variation in Corynespora cassiicola, the target leaf spot pathogen. Pakistan Journal of Biological Sciences, v.8, n.4, p.618-621, 2005. DOI: 10.3923/pjbs.2005.618.621

MOJENA, R. Hierarchical grouping methods and stopping rules: an evaluation. The Computer Journal, v.20, n.4, p.359-363, 1977. https://doi.org/10.1093/comjnl/20.4.359

NEI, M.; LI, W. Mathematical model for studying genetic variation in terms of restriction endonucleases. Proceedings of the National Academy of Sciences of the USA, v.76, n. 10, p.5269-5273, 1979.

NGHIA, N.A.; KADIR, J.; SUNDERASAN, E.; PUAD ABDULLAH, M.; MALIK, A.; NAPIS, S. Morphological and Inter Simple Sequence Repeat (ISSR) markers analyses of Corynespora cassiicola isolates from rubber plantations in Malaysia. Mycopathologia, v.166, n.4, p.189-201, 2008. DOI: 10.1007/s1 1046-008-9138-8

PINHO, D.B.; MACHADO, A.R.; FIRMINO, A.L. Princípios e métodos para identificação molecular de fungos. In: ALFENAS, A.C.; MAFIA, R.G. (Eds.). Métodos em Fitopatologia. $2^{\mathrm{a}}$ ed. Viçosa: Editora UFV, 2016. p. 389-422.

QI, Y.; ZHANG, X.; PU, J.; LIU, X.; LU, Y.; ZHANG, H.; ZHANG, H.; $\mathrm{XIE}, \mathrm{Y}$. Morphological and molecular analysis of genetic variability withun isolates of Corynespora cassiicola from different hosts. European Journal of Plant Phothology, v. 130, n. 1, p.83-95, 2011. DOI: $10.1007 / \mathrm{s} 10658-010-9734-6$

R Development Core Team (2011). R: A Language and Enviroment for Stataistical Computing. Viena, Autria: The R Foundation for Statistical Computing. ISBN 3-90051-07-0. http// www R-project.org.

RAEDER, U.; BRODA, P. Rapid preparation of DNA from filamentous fungi. Letters in Applied Microbiology, v. 1, n. 1, p.17-20, 1985. https://doi.org/10.1111/j.1472-765X.1985.tb01479.x

SHIMOMOTO, Y.; SATO, T.; HOJO, H.; MORITA, Y.; TAKEUCHI, S.; MIZUMOTO, H.; KIBA, A.; HIKICHI, Y. Pathogenic and genetic variation among isolates of Corynespora cassiicola in Japan. Plant Pathology, v.60, n.2, p.253-260, 2011 . https://doi. org/10.1111/j.1365-3059.2010.02374.x

SILVA, W.P.K.; KARUNANAYAKE, E.H.; WIJESUNDERA, R.L.C.; PRIYANKA, U.M.S. Genetic variation in Corynespora cassiicola: A possible relationship between host origin and virulence. Mycological Research, v.107, n.5, p.567-571, 2003. https:// doi.org/10.1017/S0953756203007755

SILVA-MANN, R.; VIEIRA, M.G.G.C.; MACHADO, J.C.; BERNARDINO FILHO, J.R.; SALGADO, K.C.C.; STEVENS, M.R. AFLP markers differentiate isolates of Colletotrichum gossypii from C. gossypii var. cephalosporioides. Fitopatologia Brasileira, v.30, n.2, p.169-172, 2005. http://dx.doi.org/10.1590/ S0100-41582005000200011

SOUSA, F.M.G.; BENTES, J.L.S. Variabilidade de isolados de Corynespora cassiicola (Berk. \& Curt) Wei procedentes do Amazonas, em meios de cultura. Summa Phytopathologica, v.40, n.1, p.84-87, 2014. http://dx.doi.org/10.1590/ So100-54052014000100014

VERZIGNASSI, J.R.; VIDA, J.B.; TESSMAN, D.J. Epidemias de mancha de corinespora em pepino "tipo japonês" sob cultivo protegido na Região Norte do Estado do Paraná. Fitopatologia Brasileira, v.28, n.5, p.570, 2003. http://dx.doi.org/10.1590/ so $100-41582003000500023$

VOS, P.; HOGERS, R.; BLEEKER, M.; REIJANS, M; VAN DE LEE, T.; HORNES, M.; FRITJERS, A.; POT, J.; PELEMAN, J.; KUIPER, M.; ZABEAU, M. AFLP: a new concept for DNA fingerprinting. Nucleic Acids Research, v.23, n.21, p.4407-4414, 1995. 